\title{
SOME MORPHOLOGICAL OBSERVATIONS OF CHAROPHYTES (CHARACEAE) FROM BANGLADESH
}

\author{
Sabrina Naz and Nasrin Jahan Diba \\ Department of Botany, University of Rajshahi, \\ Rajshahi-6205, Bangladesh.
}

\begin{abstract}
Morphologically interesting charophytes were found from Chapai-Nawabgonj and Rajshahi districts in Bangladesh. These are: swollen branchlet of Lamprothamnium papulosum (Wallr.) J. Groves, long stalked gametangia and twin antheridia of Nitella hyalina (DC.) Agardh, bifid bract cells of Chara flaccida A. Braun and bifid end cell of Nitellopsis obtusa (Desv.) J. Groves.
\end{abstract}

Key words: Bifid cell, long stalked oogonium, twin antheridia, morphology, Charophyta, Bangladesh

সারাংশঃ বাংলাদেশের চাঁপাইনবাবগঞ এবং রাজশাহী জেলা হতে ক্যারোফাইটার কিছু অঙ্গসংস্থানগত পর্যবেক্ষণ লক্ষ্য করা গেছে। এগুলো হলোঃ Lamprothamnium papulosum (Wallr.) J. Groves এর swollen branchlet, Nitella hyalina (DC.) Agardh এর long stalked gametangia এবং twin antheridia, Chara flaccida A. Braun এর bifid bract cells এবং Nitellopsis obtusa (Desv.) J. Groves এর bifid end cell .

\section{Introduction}

Charophytes has gained the attention of the phycologists throughout the world since early stage of phycological research (Groves and Bullock-Webster 1920, 1924; Zaneveld 1940; Pal et al. 1962; Wood and Imahori 1965; Krause 1997; Subramanian 2002; Schubert and Blindow 2003). Present communication deals with some exceptional observations found in earlier described taxa during a detailed study (Naz et al. 2011) dealing with Charophytes of Bangladesh.

\section{Materials and Methods}

Charophytes were collected from Mahananda River and wetlands (used for rice cultivation) in ChapaiNawabgonj districts, Andharshura beel at Tanor upazilla and Kharoil beel at Mohanpur upazilla in Rajshahi districts. Chapai-Nawabgonj and Rajshahi districts are located at $24.73^{\circ} \mathrm{N}, 88.20^{\circ} \mathrm{E}$ and $24.40^{\circ} \mathrm{N}$, $88.50^{\circ} \mathrm{E}$ respectively. Collected specimen were preserved in Transeau's solution (Transeau 1916) and herbarium specimen of each were also kept in the herbarium of Phycology and Limnology Laboratory, Department of Botany, University of Rajshahi in Bangladesh and Aquatic Ecology Department at University of Rostock in Germany. Photomicrographs were taken by Vivitar V3200 camera under a Reichert microscope (NR. 309209) and SONY DSC W-55 under compound microscope (Model L-101) respectively.

\section{Chara flaccida A. Braun (Fig.1: A-F; Fig. 3:C-E)}

Synonyms: C. gymnopitys Braun, Linnaea 25: 708.1852; C. benthami Braun, Monatsber. K. Akad. Wiss. Berlin (1867): 799; C. fibrosa subsp. flaccida (A. Braun)
Zaneveld, I.c., p. 162. 1940; C. fibrosa var. fibrosa f. fibrosa Wood, Taxon 11: 13. 1962.

(Pal et al. 1962, 95, Figs. 220-222; Wood and Imahori 1965, 289, 1964, Icones 125-128; Imahori and Sinha 1964; Islam and Sarma 1968, 366, Pl., 4, Figs. 29-36, Pl., 5, Figs. 37-45, Pl., 6, Figs. 53-54; Langangen and Leghari 2001,72; Subramanian 2002, 88, Pl. 32, Figs. 1-4; Naz et al.2011, 65,Pl.12,Figs.1-15)

Material studied, locality and occurrence: Col. No. C 9, December 17, 2006. Kharoil beel, Trimohini, Mohanpur, Rajshahi. Water depth up to $5 \mathrm{~cm}$; carpet like dense growth intermingled with Chara vulgaris of this specimen was found in the rice field (a part of the beel).

Bifid bract cells are frequently present and 2-celled apices of branchlet which is observed only once in the whole population of this specimen. Bifid bract cells are situated at apices of branchlet, rarely present at $2^{\text {nd }}$ node of a branchlet; one bifid cell, rest are normal; Wood and Imahori (1965) described such bract cells in Lychnothamnus barbatus (p. 346, Fig 16); Nitella translucens var. axillaris f. caroliniana (p.687, Fig.28); bifid bracteols of $C$. vulgaris f. kieneri (p.89, Fig.3).

\section{Lamprothamnium papulosum (Wallr.) J. Groves (Fig. 1: G-I; Fig. 3: A,B)}

Synonyms: Chara wallrothii Ruprecht, Beitr. Pfl. Russ. Reich. 3: 12. 1845 (=var. papulosum); Lamprothamnus alopecuroides (Del. ex A.Br.) Braun in Braun and Nordstedt, Abh. K. Akad.Wiss. Berlin (1882):100.1882 (= var. papulosum) 
(Groves and Bullock-Webster 1924, 7, Pl. 25, Figs.1-9; Pal et al. 1962, 83, Figs.182; Wood and Imahori 1965, 330, 1964, Icones 162-166; Blindow and Langangen 1995, 47; Krause 1997, 134, Fig. 53: A-J; Schubert and Blindow 2003,156, Fig. 4.18.1:A-G; Langangen 2004, 31; Langangen 2007,109; Naz and Diba 2009, 13, Fig A-D;Naz et al 2011, 44\&45, Pl.2, Figs., 1-12)

Material studied, locality and occurrence: Col No.154, March 15, 2004. Specimen collected from Mahananda River bank depression at about $15 \mathrm{~cm}$ depth intermingled with other algae e.g. Spirogyra, Chara braunii, Nitella furcata subsp. flagelliformis.

Swollen branchlet with bract cells of L. papulosum is an interesting feature in present communication. The swollen branchlet (701 $\mu \mathrm{m}$ in diameter) of this species may be new observation in home and abroad. Morphologically similar branchlets without bract cells were Chara corallinaf. Simplicissima; syn. Protochara australis (p.328 Pl., 6, Figs. 6\&7) by Wood and Imahori (1965).

\section{Nitella hyalina (DC.) Agardh (Fig. 2: A-K; Fig. 4: A-G, I-K)}

Synonyms: Chara hyalina DC. in Lam. and DC., Fl. Francaise 6: 247.1815; Chara condensata Rupr., Beitr.Pfl. Russ. Reich 3: 10. 1845 (nom. illeg.) (= var. hyalina); N. longifurca (Rupr.) Wallman, l.c., p. 24. 1853 (= var. hyalina).

(Groves and Bullock-Webster 1920, 127, Pl.16, Figs. 114 ; Pal et al. 1962, 72, Figs.133-142; Sundaralingam 1959, 19, Figs. 43-49; Wood and Imahori 1965, 655, 1964, Icones 349, 350; Islam and Sarma 1976, 60, Figs. 80-90; Krause 1997, 140, Fig.55, A-F; Langangen and Leghari 2001, 63; Subramanian 2002, 64, Pl. 18, Figs.1-4; Schubert and Blindow 2003, 186, Fig. 4.23.1: A-F; Naz et al. 2011, 94\&97, Pl. 27, Figs. 1-10; Pl.28, Figs.1-9, Pl.29., Figs. 1-9)
Material studied, locality and occurrence: Col. No. N 5, March 2, 2005. Andharshura beel, Tanor, Rajshahi. Specimens intermingled with Chara braunii were collected from rice field (part of the beel).

During present investigation the specimen is interesting which has long stalked gametangia and twin antheridia, stalk 286- $1229 \mu \mathrm{m}$ long, rarely simple ray 3-celled, dactyls sometimes unequal and various lengths in size. Islam and Sarma (1976) was the first to describe this species from Rajshahi.

\section{Nitellopsis obtusa (Desv.) J. Groves (Fig. 1: J- K; Fig. 4: H, L)}

Synonyms: Chara obtusa Desvaux in LoiseleurDeslongchamps, Not. Pl. Fl. France,p.136.1810. Nitellopsis stelligera (Bauer in Reich.) Hy, Rev. Bot. 8: 46. 1890.

(Groves and Bullock-Webster 1924, 3, Pl. 24, Figs. 1-8; Pal et. al. 1962, 80, Figs. 171-175; Wood and Imahori 1965, 351; 1964, Icon 169; Islam et. al. 1988, 58, Figs 1-5; Krause, 1997, 128, Fig. 50: A-I; Subramanian 2002, 75, Pl. 24, Figs. 1-7; Langangen et. al. 2002, 30, Fig. 20; Schubert and Blindow 2003, 216, Fig. 4.28.1: A-J; Naz et. al. 2010, 203, Pl.1, Figs.1 -12; Pl. 2. Figs.1-10; Naz et al.2011,41\&42,Pl.1,Figs.1-12)

Material studied, locality and occurrence: Col. No.1, March 15, 2004. Mahananda River, ChapaiNawabgonj. The species was found with Nitella flagelliformis.

Bifid end cell of this species is an interesting feature which was observed only once. 


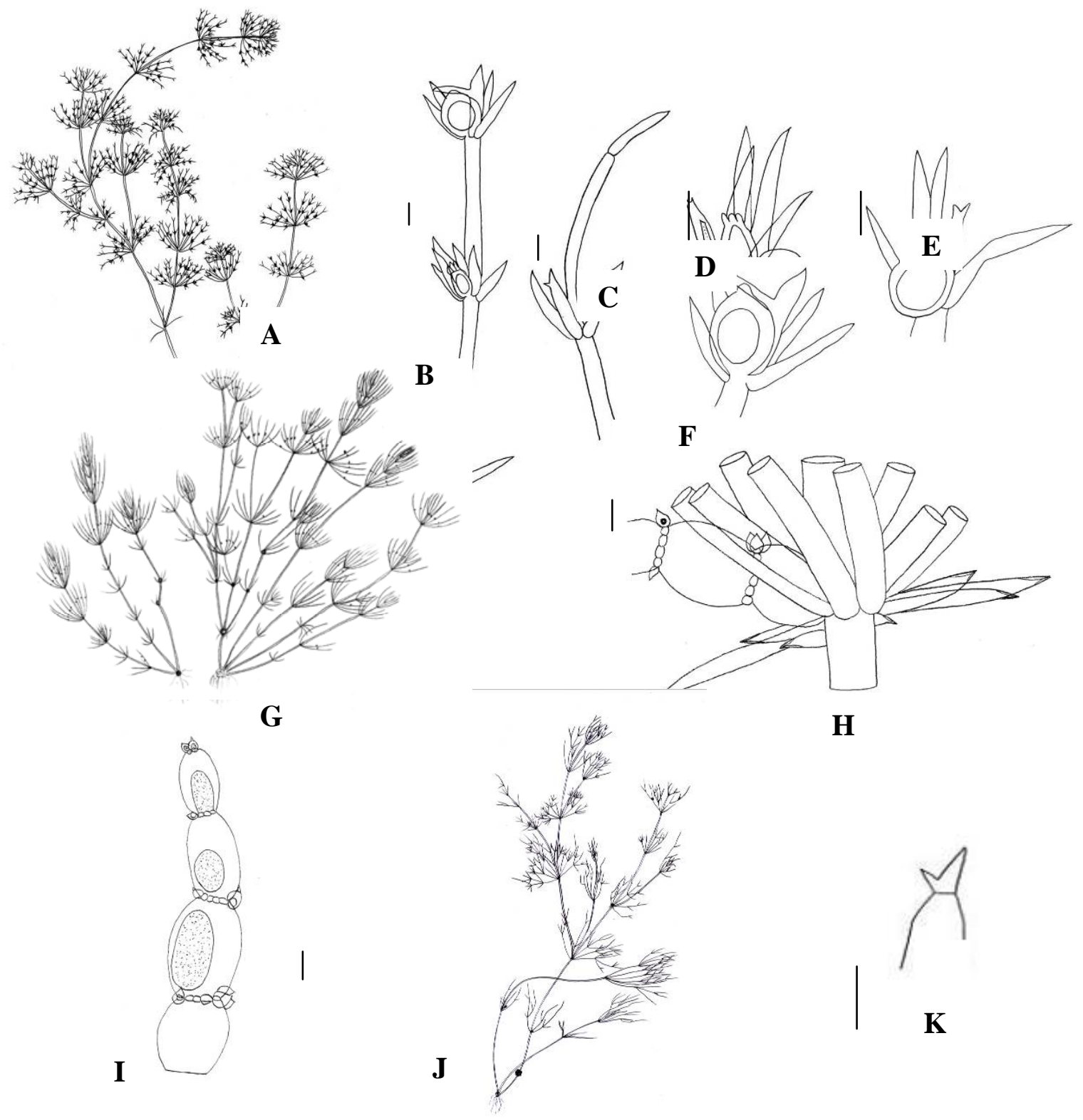

Figure. 1 (A-F) Chara flaccida A. Braun (A) Habit (B) A branchlet (C) 2-celled apices of branchlet (D-F) Apices of branchlet with bifid bract cells; (G-I) Lamprothamnium papulosum (Wallr.) J. Groves (G) Habit (H) Stipulodes with swollen branchlet (I) A swollen branchlet; (J,K) Nitellopsis obtusa (Desv.) J. Groves (J) Habit (K) Bifid end cell.(Scales=0.2 mm) 


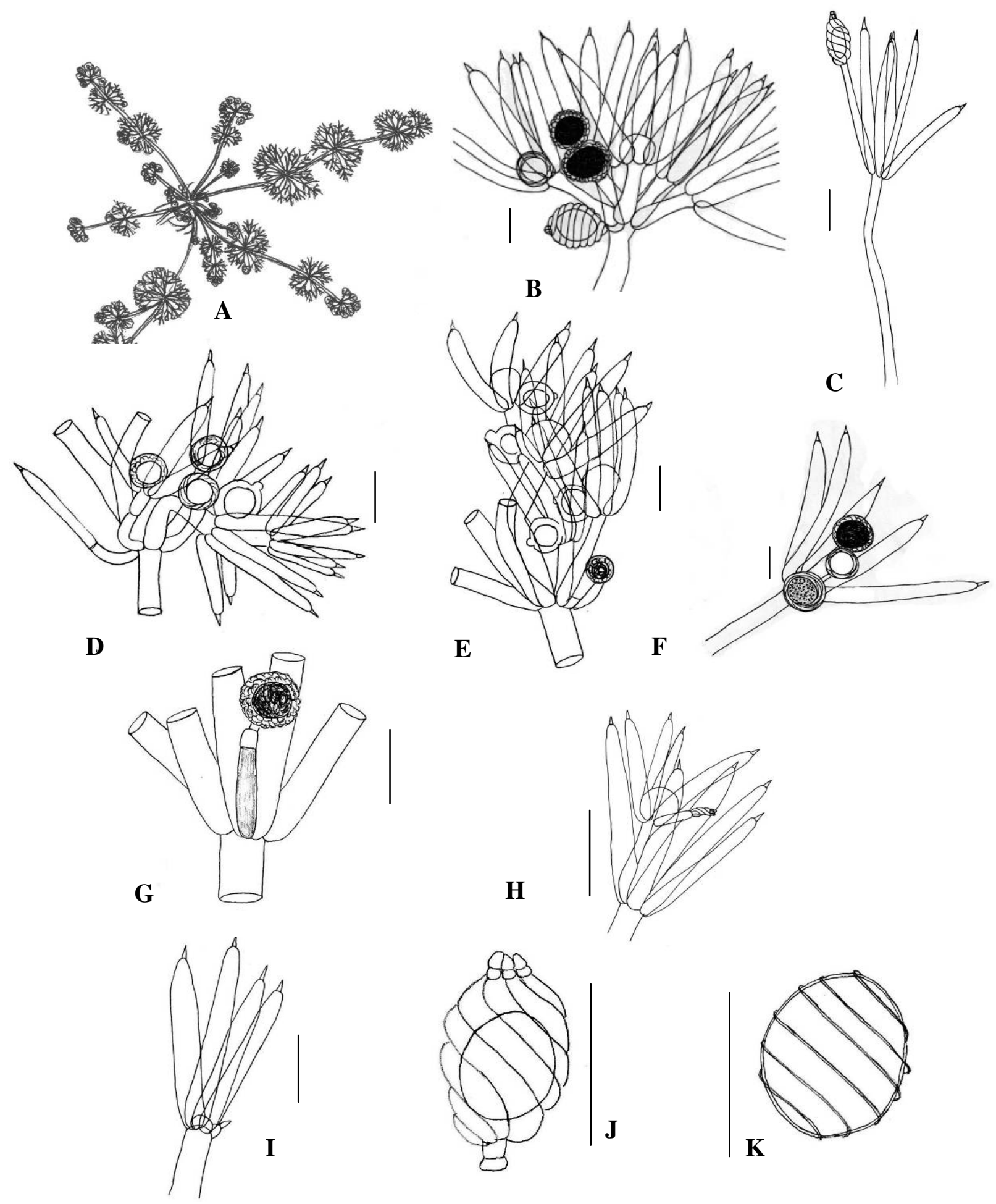

Figure 2 (A-K) Nitella hyalina (DC.) Agardh (A) Habit (B) A branchlet with twin antheridia (C,H) Long stalked oogonium (D) 3-celled simple ray (E,G) Stalked antheridium (F) Accessory branchlet with stalked gametangia (I) Unequal dactyls (J) Oogonium (K) Oospore.(Scales=0.2 mm) 

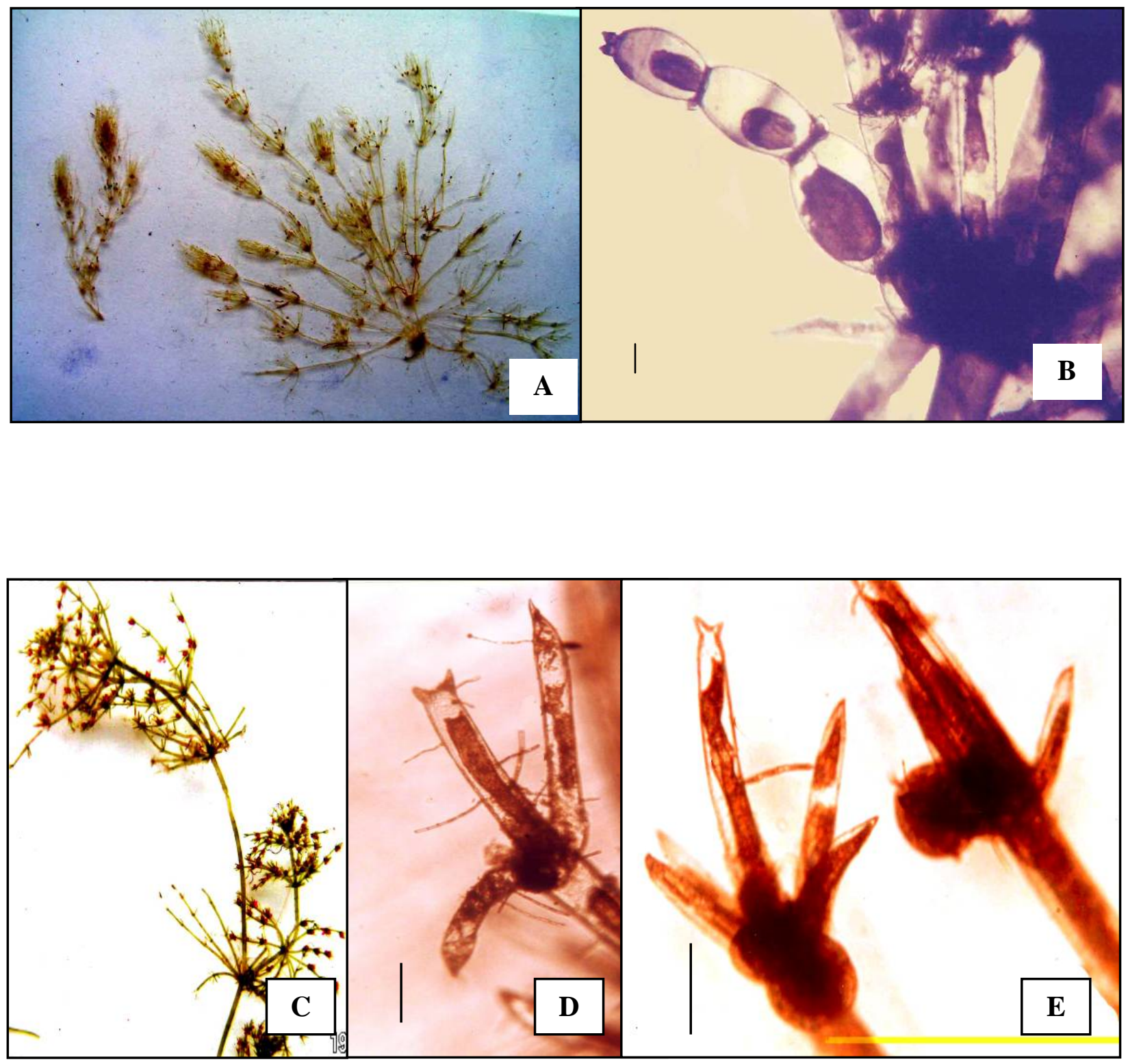

Figure 3 (A-B) Lamprothamnium papulosum (Wallr.) J. Groves (A) Habit (B) Swollen branchlet; (C-E) Chara flaccida A. Braun (C) Habit (D,E) Bifid bract cells. (Scales= $0.2 \mathrm{~mm}$ ) 

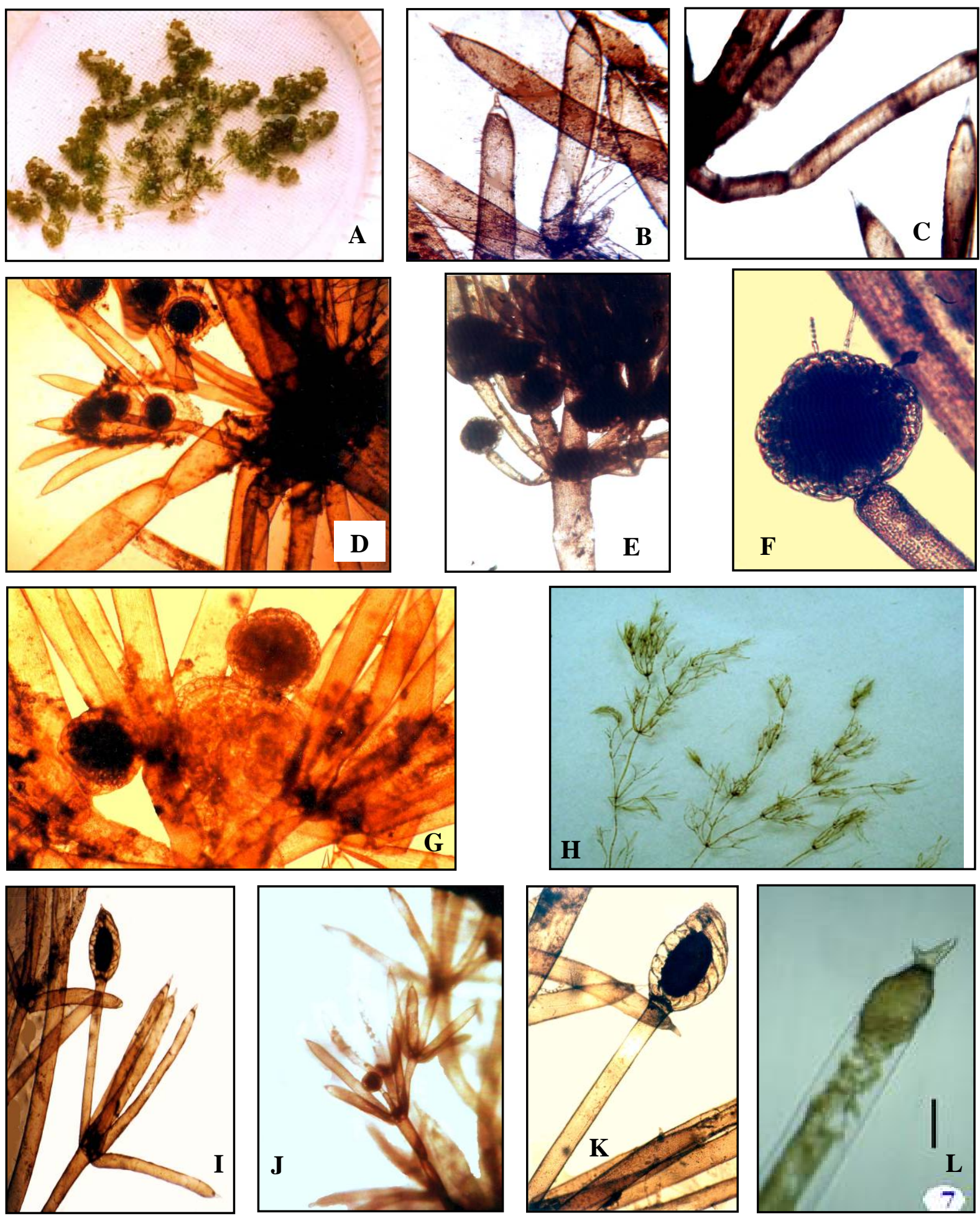

Figure. 4 (A-G) (I-K) Nitella hyalina (DC.) Agardh (A) Habit (B) Unequal dactyls (C) 3-celled simple ray (D) Long stalked gametangia with thick mucus (E) A whorl with stalked antheridium (F) An antheridium (G) Twin Antheridia (I,K) 
Some Morphological Observations of Charophytes

Long stalked oogonium (J) An accessory branchlet with long stalked antheridium; (H,L); Nitellopsis obtusa (Desv.) J. Groves $(\mathrm{H})$ Habit $(\mathrm{L})$ Bifid end cell. (Scales= $0.2 \mathrm{~mm}$ )

Acknowledgement: The authors acknowledge to the Institute of Biological Sciences (IBSc), University of Rajshahi, Bangladesh for the financial support provided during the study.

\section{References}

Blindow I and Langangen A. 1995. Lamprothamnium papulosum (Wallr.) J. Groves, a threatened Charophyte in Scandinavia. Crypt. Algol. 16:47-55.

Groves J and Bullock-Webster GR. 1920. The British Charophyta. Vol. I. Nitelleae with introduction, plates and text figures. Ray Society London.141 pp.

Groves J and Bullock-Webster GR. 1924. The British Charophyta. Vol. II. Chareae with plates, concluding articles, geological sketch, bibliography and index. Ray Society London. $129+$ XXII-XLV.pp.

Imahori K and Sinha JP. 1964. Notes on the Asiatic Charophyta. IV. specimens from Ranchi (India) and Nepal Adv. Front. Plant Sci. Institute Adv Science and Culture, New Delhi. 8: 55-68.

Islam AKMN and Sarma D. 1968. The Characeae of East Pakistan. 1. Lychnothamnus and Chara. J. Asia Soc. Pak. 13(3): 357-379.

Islam AKMN, Sarma D. 1976. The Characeae of Bangladesh II. Genus Nitella. J. Asia. Soc. Bangladesh (Sc.). 2(1):43-61.

KrauseW.1997.Charales(Charophyceae).Süßwasserflora von Mitteleuropa, band 18. Gustav Fischer Verlag. 202 pp.

Langangen A. 2004. Charophytes from four Cyclade Islands (Mykonos, Naxos, Paros and Antiparos) in Greece. J. Biol. Res. 1: 31-38.

Langangen A. 2007. Some Charophytes from the Western Cyclads (Greece). J. Biol. Res.7: 109-113.

Langangen A and Leghari SM. 2001. Some Charophytes (Charales) from Pakistan. Stvelia. Bot. hung. 32: 63-85.
Naz S and Diba. NJ. 2009. Genus Lamprothamnium J. Groves. In: Encyclopedia of flora and fauna of Bangladesh. Algae, Charophyta-Rhodophyta (Achanthaceae-Vaucheriaceae). (eds. ZU Ahmed, M Khondker, ZNT Begum, MA Hasan, SMH Kabir, M Ahmed, ATA Ahmed and AKA Rahman). p. 13. Asiatic society Bangladesh, Dhaka.

Naz S, Diba NJ and Zaman M. 2010. Nitellopsis obtusa (Desv.) J. Groves. A new Charophytic record for Bangladesh. Bangladesh J. Plant Taxon. 17(2): 203-207.

Naz S, Diba NJ and Schubert H. 2011. Monograph on Charophytes of Bangladesh. VDM Verlag Dr. Müller GmbH \& Co. KG. 216 pp.

Pal BP, Kundu BC, Sundaralingam VS and Venkataraman GS 1962. Charophyta. Monographs on algae. Vol 5. Indian Coun. Agr. Res.New Delhi. $\mathrm{x}+130$ pp.

Schubert H and Blindow I. 2003. Charophytes of the Baltic Sea. The Baltic Marine Biologists Publication No. 19. Alfried Krupp von Bohlen und Halback Stiftung. A.R.G. Gantner Verlag, Kommanditgesellschaft,Ruggell.326+ VI.pp.

Subramanian D. 2002. Monograph on Indian Charophyta. Bishen Sing Mahendra Pal Sing, 23-A.Connaught place, Dehra Dun. VI + 115. pp.

Sundaralingam VS. 1959. A systematic account of the South Indian Characeae. Proc. Indian Acad. Sci. 49B: 7-51.

Transeau EN. 1916. The periodicity of fresh water algae. Amer. J. Botany. 3: 121-133

Wood RD and Imahori K. 1964. A revision of the Characeae. Part II. Iconograph of the Characeae. Verlag Von. J. Cramer, Weinheim. I-XV + Icon 1-395 pp.

Wood RD and Imahori K. 1965. A revision of the Characeae. Part-I; Monograph of the Characeae. Verlag Von, J. Cramer, Weinheim. 904 pp.

Zaneveld JS. 1940. The Charophyta of Malaysia and adjacent countries. Dissertation University Leiden. Blumea. 4: 1-223.

Manuscript received on 05 November 2012 and revised on 29 December 2012 
